\title{
Role of slotting fees and trade promotions in shaping how tobacco is marketed in retail stores
}

Paul N Bloom

\begin{abstract}
Objective-To examine how the retail environment in which tobacco is sold has changed because of the slotting fees and trade promotions paid by the tobacco companies. Public policy options for dealing with this environment are also evaluated.

Data sources-A literature review, telephone interviews, and observation.

Results-The tobacco companies have been dramatically increasing the volume of slotting fees and trade promotions they pay to retailers, creating a more tobacco friendly retail environment containing self service displays and ample point-of-sale advertising. Critics express concern that these payments have kept prices lower and more varied than they might be otherwise, created more opportunities for pilferage and underage selling, and provided more youth exposure to tobacco promotions. Public policy makers could either ban these payments, institute policies designed to mitigate their harmful effects, or leave the situation as it is, relying on enforcement of existing statutes as well as market forces to reduce harm. Actions that might mitigate harmful effects would include putting minimum retail prices on tobacco products, banning self service displays, requiring retailers to be licensed, and adding more warning signs at the point of sale.
\end{abstract}

Conclusion-Additional research is needed before determining the most appropriate public policy stance.

(Tobacco Control 2001;10:340-344)

Keywords: promotion; slotting; retailing; merchandising

The ways in which tobacco products are displayed and promoted in retail stores have recently gone through considerable changes, influenced in part by the growth in the payment of slotting fees (that is, payments to obtain space to display products and/or promotional materials) and trade promotions to retailers by tobacco companies. The Federal Trade Commission reports that the tobacco companies have been steadily increasing their spending on these fees and promotions, with $\$ 3.54$ billion or $43 \%$ of their promotional budget being devoted to trade promotions in 1999 , up from $\$ 856$ million or $33 \%$ in $1987 .{ }^{1}$ These fees and promotions take many forms (for example, cash, rebates, free products, display cases). They are used to encourage retailers to create more tobacco friendly environments containing enticing displays, competitive prices, and visible point-of-sale advertising.

Critics of these fees and promotions argue that they help to create a retail environment that stimulates an unhealthy "lift" in sales, ${ }^{2}$ with much of the increased purchases coming from new or occasional smokers. There is particular concern that young people are being tempted to smoke by this more tobacco friendly environment, and some argue that the fees and promotions encourage stores to be lax about youth pilferage and underage sales.

This paper examines tobacco company slotting fees and trade promotions, covering their causes, effects, and public policy options for controlling them. The discussion is based on a literature search of reports, web sites, journal articles, trade press stories, and available tobacco industry documents. In addition, telephone interviews were conducted with five retailers of tobacco products plus four authors of recent reports on tobacco retailing. Furthermore, tobacco retailers in several states were visited to observe their practices.

\section{Recent changes in tobacco retailing}

The historic emphasis in the tobacco industry on achieving widespread, intensive, self service distribution has changed. Vending machines are disappearing through regulation and public pressure. ${ }^{3}$ Further, many supermarket, drug store (pharmacy), and convenience store chains have made tobacco less accessible to their customers, putting them either in locked Plexiglas displays or in highly visible behind-the-counter racks, giving the stores more control over pilferage and underage buying. Other convenience stores and small "ma and pa" retailers have also eliminated self service displays, often because local ordinances have required them to do so. ${ }^{4}$ And some have eliminated self service because Philip Morris recently instituted a policy of giving higher payments per carton sold to stores that meet sets of requirements, one of which is keeping all cigarettes behind the counter in Marlboro display cases.

Still, many convenience, "ma and pa", and liquor stores in certain parts of the country are filled with self service racks and open cigarette cartons, often near the main checkout. ${ }^{5}$ Moreover, self service flourishes in the rapidly growing cigarettes only retailers (for example, Cigarettes Cheaper!). ${ }^{6}$ Along with these shifts in self service activity, the retail environment has seen a steady upswing in the amount of in-store and parking lot banners, retailer 
billboards, signage, clocks, shopping baskets and carts, and change trays that feature the brand names and prices of cigarettes. ${ }^{48}$

Thus, the grocery and drug stores, as well as the convenience stores that prohibit self service displays, are not the fertile places they once were to get established smokers to switch and try out a new brand. They also are not as good as they used to be for tempting young people to initiate tobacco use. These stores, along with the mail order and internet retailers, ${ }^{9}$ are more likely to be catering to brand loyal, established smokers. It is the other self service oriented, advertising saturated, convenience, "ma and pa," liquor, and tobacco only stores where the tobacco companies now see their best opportunities for attracting new customers, and they are reportedly targeting their sales efforts and promotion spending toward those stores. ${ }^{10}$ Evidence of their interest in these retailers can be found in the documents submitted by the attorneys for RJ Reynolds and the other smaller tobacco companies in their current lawsuit challenging the alleged exclusionary trade promotion practices of Philip Morris. ${ }^{1112}$

\section{Probable causes of today's retail environment}

A number of forces are likely to be responsible for the current retail environment for tobacco products. The increased regulatory and enforcement efforts that have been devoted to reducing underage tobacco sales have likely had a big impact, as larger chains and stores have become wary of making it easy for young people (or others) to obtain tobacco by stealing and have therefore eliminated self service. Further, the elimination of billboard advertising and other selected forms of promotion (for example, limits on sponsorships) through the Master Settlement Agreement (MSA) has probably freed up tobacco company funds to use to either reduce prices or spend on slotting fees and other trade promotions.

Tobacco retailing has also probably been heavily influenced by some evolutionary trends in consumer goods marketing. There has been increased emphasis on "relationship marketing" between manufacturers and retailers (that is, developing partnerships to enhance efficiencies) and a shift toward using "push" marketing tools (for example, sales calls, trade allowances, slotting fees, and display fees) over increasingly less effective "pull" marketing tools (for example, media advertising).

Thus, in reaction to policy and legal developments, as well as to shifts in the way all consumer products are being distributed and promoted, the tobacco companies have developed their own new style of promoting their products. They are employing very heavy spending on slotting fees and trade promotion to help create today's retail environment for tobacco. The slotting fees are not just being used to obtain shelf space for new products, as they tend to be in the grocery industry, but are being used to achieve a variety of goals.

In working with retailers, the tobacco companies seem to offer deals that vary based on the currency of payment and the requirements for payment. The currencies offered to retailers include cash, reductions (or allowances) on the invoices for cases sold to the retailers, free cases, free or discounted equipment (for example, display cases, shopping carts, clocks), or free entertainment (for example, NASCAR (auto racing) tickets, free vacations, clothing). The terms buydowns (payments made either in cash or as off-invoice allowances to encourage the retailer to reduce the price of products currently held in inventory) and rebates (payments made in cash or as off-invoice allowances to retailers who have achieved certain sales volumes) are frequently used in the industry.

The requirements the tobacco companies may place on the retailers may contain expectations about how certain brands will be treated in terms of number of shelf facings, shelf heights, locations, types of displays, self service availability, in-store advertising, and prices. The more requirements met by a retailer, the greater the amount of the payments offered. For example, it has been reported that Philip Morris has paid a retailer $\$ 0.30$ per carton sold from a self service display but only $\$ 0.15$ per carton sold from a non-self service display, although the company has apparently discontinued this practice. ${ }^{13}$ Similarly, Brown and Williamson offers retailers between $\$ 290$ and $\$ 365$ per month per store depending on the nature of displays used. ${ }^{14}$ Indeed, convenience stores have been reported to make the cash equivalent of as much as $\$ 20000$ per store per year by cooperating fully with relationship marketing programmes (sometimes called Cooperative Merchandising Agreements) such as Philip Morris' Retail Leaders Program. ${ }^{13}$ Interestingly, these programmes have been a centre of controversy in the industry, as even RJ Reynolds, the number 2 manufacturer, has felt excluded and harmed by the Retail Leaders Program of Philip Morris, filing a suit along with other manufacturers to have it discontinued. ${ }^{12}$ Similarly, a programme that US Tobacco apparently used to help it dominate retail shelf locations for smokeless tobacco products was found to be illegal in a jury trial in US district court, providing Conwood Company, its smaller competitor, with a relief award of over $\$ 1$ billion. ${ }^{16}$

Besides influencing the displays and point-of-sale advertising in retail stores, ${ }^{17}$ the spending on slotting fees and trade promotions has apparently helped the tobacco only retailers grow. It appears that Philip Morris has been extremely supportive of these specialty retailers and has offered them attractive partnership arrangements. ${ }^{6} 18$ Perhaps the company sees these retailers as providing downward pressure on all retail prices, and they may be seen as less likely to be targets of public criticism, since they promote themselves as being places that prohibit entry by minors. 


\section{Social effects of slotting fees and trade} promotions

Slotting fees and trade promotions could be contributing to social problems in the USA through several mechanisms examined below.

EFFECT ON RETAIL PRICES

Trade deals give retailers more flexibility on pricing, allowing them to charge less for certain brands at certain times. Trade deals have also probably stimulated the development of the tobacco only retailers, which have put downward pressure on prices. At the very least, it can be argued that trade deals create more variation in prices over time. Perhaps this gives tobacco consumers less of a feeling that they need to quit to avoid an escalating financial burden. More than likely, overall price levels on tobacco products have also remained lower than they might be without trade deals.

The study of post-MSA retail promotion behaviour by Wakefield and colleagues ${ }^{7}$ found that cents-off promotions increased in prevalence from $32 \%$ to $41 \%$ of the stores they observed across the USA. Additionally, Federal Trade Commission (FTC) data indicate that "retail value added" spending on offers such as "buy one, get one free" or "buy one and get a free lighter" grew from $\$ 1.56$ billion in 1998 to $\$ 2.56$ billion in 1999 , accounting for $31.1 \%$ of the total advertising and promotion spending in the industry. ${ }^{1}$ Indeed, the MSA may have created more harm than good when it removed billboard advertising (reducing overtures to young people) while it stimulated increased spending on trade deals and value added (and thereby stimulated lower real prices and higher consumption). In other words, the MSA may have backfired in this area.

EFFECT ON SELF SERVICE, PILFERAGE, AND UNDERAGE SALES

Historically, the payments the tobacco companies have made for maintaining self service displays have been substantial. Recently, Philip Morris has offered retailers the same or better trade deals if they eliminate self serviceassuming they meet other requirements (for example, volume, behind-counter displays) but the other tobacco companies continue to pay more for self service displays than clerk controlled ones. Besides encouraging pilferage, self service displays may create temptation for smokers who are trying to cut down or quit or for young people who are contemplating initiation. Indeed, critics of the industry argue that the tobacco companies give payments to retailers as a way to compensate them for the losses they incur from pilferage of self service displays. These critics argue that the companies see this pilferage as a way to get young people hooked on tobacco without having to make any illegal sales to them. To support their arguments, the critics point to studies that indicate that between $3.5-6.8 \%$ of young smokers stole their cigarettes. ${ }^{19}$ They also point to older documents from the industry that seem to show that tobacco company executives, at least in the past, recognised the value to them of compensating retailers for pilferage. ${ }^{8}$

The tobacco companies argue that instead of trying to encourage youth pilferage they have initiated a variety of programmes to discourage underage sales. But the effects of industry sponsored programmes such as "We Card" can be called into question based on the results of a recent California study that found that stores that had the industry "We Card" signs had significantly more illegal sales then stores that had government warning signs. ${ }^{20}$

It is also possible that the warm relationships the tobacco company sales representatives have formed with clerks and personnel of retailers, through their relationship marketing programmes that provide valuable gifts to clerks, has contributed to the clerks being a little more lax about checking identification with young people. However, there is no persuasive empirical evidence on this issue. ${ }^{21}$

EFFECT ON TOBACCO FRIENDLY ENVIRONMENTS AND YOUTH INITIATION

There can be little doubt that those retailers who take larger amounts of slotting and promotional dollars from the tobacco companies have created tobacco friendlier environments. ${ }^{17}$ What is less clear is whether the tobacco friendlier environments, including all of its in-store advertising, are having an impact on the behaviour of smokers or young people contemplating initiation. Research that has established a strong causal link between retail site promotional activities and consumer behaviour has not been completed. The best that has been done is to identify an association between tobacco industry promotional activities and the attitudes and behaviours of young people. For example, Voorhees and colleagues ${ }^{22}$ found that the more youth oriented advertisements were displayed outside retail stores, the more often young people tried to buy cigarettes. Additionally, Schooler and associates $^{23}$ found that 13 year olds who reported seeing tobacco marketing in stores were $38 \%$ more likely to experiment with smoking.

EFFECT ON POLITICAL SUPPORT FROM RETAILERS By providing lucrative fees and promotions to retailers, the tobacco companies increase the chances that retailers will become their vocal allies in political debates at the local, state, national, and international level. ${ }^{13}$ The political clout of these retailers, who are often well organised to mount lobbying efforts, can potentially influence public policy decisions in a pro-tobacco direction.

\section{Public policy options}

Three basic stances that public policy makers could take toward slotting fees and trade promotions in the tobacco industry are examined below.

BANNING SLOTTING FEES AND TRADE PROMOTIONS

There is a precedent for banning slotting fees and similar trade deals. In 1995, they were eliminated from the marketing of alcohol 
beverages by the Bureau of Alcohol, Tobacco, and Firearms. ${ }^{24}$ This action was primarily taken to protect small wineries and breweries from being excluded from retail shelves because of payments by larger rivals. However, there was also some concern that the payments could create too close a relationship between alcohol beverage manufacturers and retailers, increasing the chances for excessive promotion of alcohol use at the point of sale. ${ }^{25}$

Banning slotting fees and trade promotions in the tobacco industry, as has been done in the alcohol beverage industry, could have many benefits. Foremost, it would cut down the pressure that retailers feel to acquiesce to the desires of the tobacco companies and provide low and varied prices, self service displays, and tobacco friendly environments - or else risk losing tobacco sales to rivals that are cooperating with the tobacco companies. A ban would also reduce the incentives for retailers to become close political allies with the tobacco companies.

However, there are dangers associated with a ban. It could allow the tobacco companies to call a truce on trying to out-deal one another, saving them billions of dollars in the process. The companies could then use these savings to cut the price dramatically on tobacco products and this could lead to more tobacco sales than might be the case if the trade deals were allowed to continue.

\section{ATTEMPTING TO MITIGATE HARMS}

Assuming slotting fees and trade promotions are not banned, there are a number of other steps that public policy makers could take to try to mitigate the harms caused by these tools. First, minimum resale prices could be set on tobacco products, which could eliminate the demand stimulation that slotting fees and trade promotions can accomplish through their role in encouraging lower retail prices. In New York state, it is unlawful for retailers to sell below cost plus a statutorily determined minimum percentage markup. In calculating cost, the state does not allow the deduction of slotting fees or trade allowances, preventing the passing on of these types of discounts to consumers. For the most part, this is done to ensure that the state gets its full share of tobacco sales tax revenues, but it could be having the secondary effect of mitigating the harmful effects of slotting fees and trade promotions.

Another approach could involve the banning of self service displays, which has already been done in many communities. Indeed, a ban on self service displays coupled with strict enforcement of age identification checks could do much to minimise the harms created by trade deals. However, such a policy approach would be consistent with Philip Morris' current strategy of discouraging self service and encouraging participation in the "We Card" programme. Perhaps it is doing this because it knows its strong, well established brands will benefit from limiting the competitive options of its rivals.

Another step that could be taken is mandatory licensing of tobacco retailers, which has been implemented in many communities. Fear of losing a very profitable licence to sell tobacco would increase the incentives for the retailer to police underage sales very vigorously, regardless of trade deal activity. Although enforcement expenses would arise, these could be covered by the license fees. Moreover, stores might respond to these fees by choosing not to carry tobacco products or raising prices, reducing tobacco availability to many and potentially reducing consumption. Naturally, retailers can be expected to organise politically against licensing.

Requiring retailers to post larger and more numerous signs about the consequences of selling tobacco to young people is another option. At a minimum, attempts could be made to ensure that warning signs are not removed, which one study found happened in stores that received trade deals. ${ }^{26}$. A Stanford study found that stores that never sold to minors in a youth purchase survey in one community had nearly twice as many age of sale signs on or within 4 feet $(1.2 \mathrm{~m})$ of the counter area. ${ }^{21}$ Of course, the type of sign and the manner in which it is offered to the retailer may impact its effectiveness. As discussed earlier, stores that had the "We Card" signs from the industry sponsored programme actually had more illegal sales than stores that had government created signs. ${ }^{20}$ This may have happened because participation in the "We Card" programme may have led retail clerks to be more relaxed about checking identification. Or the "We Card" signs, which are typically located near the counter, may be getting lost in all the clutter in that area and may have also become too familiar.

Self service bans and vigorous identification checking would not prevent the huge volume of in-store, front window, and parking lot advertising from continuing. To the extent that former smokers may be influenced by these messages to relapse or that children may be influenced to initiate smoking, then it might be tempting to try to restrict some or all of these forms of promotion. This could include a ban on outdoor advertising of tobacco products by retailers, which is something that was not banned by the MSA.

A problem with restricting point-of-sale promotional materials is figuring out which restrictions would be viewed as infringements on First Amendment free speech rights and which would not? The courts would certainly weigh in on this matter, as they already have in a case involving advertising restrictions in Massachusetts. Furthermore, in the past, the tobacco companies have shown great ingenuity in finding new ways to overcome having limits put on their promotional efforts. ${ }^{72}$ Moreover, there is also the risk that they would use the funds saved to just lower their prices.

RELY ON ENFORCEMENT OF EXISTING STATUTES AND MARKET FORCES

The option exists to do nothing special about slotting fees and trade promotions, hoping that a certain amount of the problems created will resolve themselves as the public becomes more 
informed and wary about retail tobacco promotions, as enforcement of existing youth access laws increases, and as market forces continue to play out. In this latter category, it is conceivable that the growth of the tobacco only retailers could make the tobacco promotion practices of other types of retail stores relatively unimportant. However, it is unlikely that the tobacco companies would allow the tobacco only retailers to become dominant, since they need the other retailers to help them entice new smokers. The tobacco only stores are unlikely to attract much non-smoker traffic, especially since they purportedly prohibit entry by minors.

\section{Conclusions}

Before taking any strong actions against slotting fees and trade promotions, it would be helpful for public policy makers to have additional information. It would be particularly useful to have a better grasp on how retail prices have been affected by the recent policy actions and the resulting increase in trade-deal activity. If prices are lower than they might have been had billboard advertising not been banned (and only fines imposed) by the MSA, then it might suggest that additional bans on trade deals or in-store promotional materials could backfire and lead to demand stimulating price cuts by the tobacco companies.

Of course, any demand stimulation created by lower prices might be worth tolerating if fewer tobacco friendly retail environments were created, with a lot fewer young people being influenced by these environments to initiate or continue smoking. Therefore, it is important for research to be done on how young people respond to tobacco friendly retail environments that are filled with promotional materials and few warning signs. There is some evidence that more tobacco friendly environments are associated with higher numbers of youth purchase attempts $^{22}$ and higher likelihood of youths experimenting with smoking. ${ }^{23}$ But it is unclear whether the environments have caused the reported smoking behaviours or whether the tobacco companies and retailers have set up more tobacco friendly stores in markets that are more likely to have young people making purchase attempts and intending to smoke. Better evidence on the direction of causality is needed.

1 Federal Trade Commission, Report to Congress for 1999, Pursuant to the Federal Cigarette Labeling and Advertising Act. Washington DC: Federal Trade Commission, 2001.

2 Point-of-Purchase Advertising Institute. The point-ofpurchase advertising industry fact book, Englewood, New purchase advertising industry fact book, Englewood,

3 Centers for Disease Control. See the website: www.cdc.gov/ tobacco/research_data/legal_policy, 2000.

4 Feighery EC, Schleicher N, Halvorson S, et al. An eleven month follow-up study of stores surveyed in 1999 to determine changes in tobacco advertising and tobacco company paid incentives to retailers. Tobacco Control Section, California Department of Health Services, 2000.

5 Schott K. Tobacco, Candy often sold side by side, survey shows. The Columbus Dispatch, 17 June 2000

6 Tanner L. Burnin' it up. Dallas Business fournal, v. 23, issue 16, 10 December 1999, 1 .

7 Wakefield MA, Terry YM, Chaloupka FJ, et al. Changes at the point-of-sale for tobacco following the 1999 Tobacco the point-of-sale for tobacco following the
Billboard Ban Am $\mathcal{F}$ Public Health (in press).

8 Kline RL. Tobacco advertising after the settlement: where we are and what remains to be done, Kansas fournal of Law E Public Policy 2000;9:issue 4

\section{What this paper adds}

A variety of web sites, reports, and research studies have suggested that slotting fees and trade promotions offered by the tobacco companies are responsible for creating a retail environment that stimulates an unhealthy "lift" in tobacco sales, with much of the increased purchases coming from new or occasional smokers. There is particular concern that young people are being tempted to smoke by this more tobacco friendly environment filled with advertising and eye catching displays, and some argue that the fees and promotions encourage stores to be lax about youth pilferage and underage sales.

In this article, the previous work on tobacco industry slotting fees and trade promotions is synthesised, evaluated, and supplemented. Additional potential negative effects of the fees and promotions, such as creating lower and more varied prices, are identified. Moreover, public policy options, such as eliminating these fees and promotions or seeking to mitigate their effects through requirements like retail licensing or bans on self service displays, are critically assessed.

9 Armstrong L. All the tar and none of the taxes. Business Week, 7 December 1999

10 Ono Y. Tobacco: for Philip Morris, every store is a battlefield. Wall Street fournal, 29 June 1998

11 Lubove S. Brand power. Forbes, 9 August 1999, 98-104.

12 RJ Reynolds Tobacco Company v. Philip Morris Inc. (1999), Civil Action No. 1:99cv/85, U.S. District Court, Middle District of North Carolina.

13 Association for Nonsmokers. Slotting/promotional fees/ premium payments: hooking retailers with cash, hooking kids on tobacco. Report distributed on world wide web. St Paul, Minnesota: ANSR, 2000.

14 Private Document.

15 Segal D. PM rivals sue over display racks. The Washington Post, 14 September 1999, E1.

16 Conwood Co. v. U.S. Tobacco Co. et al. (2000), Civil Action No. 5:98-CV-108-R, U.S. District Court for the Western District of Kentucky.

17 Feighery EC, Ribisl KM, Schleicher N, et al. Tobacco marketing in stores and tobacco industry incentives paid to retailers: what's the connection? Working paper, Stanford Center for Research in Disease Prevention, Stanford University Medical Center, grant 94-20967-A04, 1999.

18 Ferguson TW.Vices are not crimes. Forbes, 20 May 1996, 56. 19 Florida Department of Health. Florida Youth Tobacco Survey $1999 ; 2(2): 10$

20 Cowling D, Robins DM. Rate of illegal tobacco sales to minors varies by sign type in California. Am f Public Health 1999;90:1-2.

21 Feighery EC, Ribisl KM, Schleicher N, et al. Assessment of the relationship between tobacco advertisements and sales in one California community. Working paper, Stanford Center for Research in Disease Prevention, Stanford University Medical Center, grant 94-20967, 1999.

22 Voorhees CC, Yanek LR, Stillman FA, et al. Reducing cigarette sales to minors in an urban setting: issues and opportunities for merchant intervention. Am f Prev Med 1998; 14:138-42.

23 Schooler C, Feighery EC, Flora JA. Seventh graders' self-reported exposure to cigarette marketing and its relationship to their smoking behavior. Am f Public Health 1996;86:1216-21.

24 Bloom PN, Gundlach GT, Cannon JP. Slotting allowances and fees: schools of thought and the views of practicing managers. Fournal of Marketing 2000;64:92-108.

25 Gundlach GT, Bloom PN. Slotting allowances and the retail sale of alcohol beverages. Fournal of Public Policy $\mathcal{E}$ Marketing 1998;17:173-84.

26 Velasquez Z, Hessing R. Post settlement: increases in storefront advertising and what can be done. Report distributed by the Santa Clara Valley Public Health Department, San Jose, California, 1999.

27 Fraser T. Phasing out of point-of-sale tobacco advertising in New Zealand. Tobacco Control 1999;7:82-4. 